\title{
Resensie-artikel
}

\section{'n Bevrydende woord vir Afrika? The Liberating Message van B.J. van der Walt}

\author{
Pieter Verster \\ Departement Sendingwetenskap \\ Universiteit van die Vrystaat \\ BLOEMFONTEIN \\ E-pos: versterp@tlg.uovs.ac.za
}

Abstract

\begin{abstract}
A liberating word for Africa? The Liberating Message by
B.J. van der Walt

B.J. van der Walt in his important work, The Liberating Message, emphasised the need for the Africanisation of Christian philosophy and theology. There can be no doubt that he introduced very important issues in the current debate. The question, however, must still be asked whether The Liberating Message offers us more than a Western view on African issues. If this is so, a further question remains whether there can be an African worldview with a Reformed Christian emphasis without changing the very emphasis of Africa itself. According to the author of this article, this question is still very relevant.
\end{abstract}

\section{Inleiding}

B.J. van der Walt, voor sy aftrede as direkteur van die Instituut vir Reformatoriese Studies aan die $\mathrm{PU}$ vir $\mathrm{CHO}$, het 'n belangrike bydrae gelewer tot die debat oor hoe ware bevryding in 'n nuwe Afrika tot stand gebring kan word. Veral belangrik is die werk The Liberating Message wat in 1994 verskyn het. Dit is opgevolg met 'n Afrikaanse weergawe Visie op die werklikheid in 1999. Die vrae wat hy in dié debat op die tafel geplaas het, is van essensiële belang. 


\section{Sentrale temas}

\section{Watter sentrale temas word aangebied?}

- Die kritiek op die Westerse en Afrika-lewenswyse en -wêreldbeskouing.

- Die betekenis van die Reformatoriese lewensvisie vir Afrika.

- Die bevryding in Afrika deur middel van die evangelie van Jesus Christus as omvattende benadering wat elke duimbreedte van die bestaan insluit.

- Die hoop op 'n nuwe toekoms vanuit die verhouding met Jesus Christus.

- Die kerk as sentrum waar die bevryding begin, maar ook die beperking van die kerk ten opsigte van sy taak in die wêreld.

Van der Walt poog om 'n nuwe beskouing ten opsigte van die wêreld moontlik te maak. Hy is van mening dat sowel die Westerse as die Afrika-lewensvisie deur die Christelike Reformatoriese lewensvisie vervang moet word. As motivering vir dié siening noem hy die volgende: die Westerse rasionalisme en sekularisme verduister die Christelike lewensvisie in so 'n mate dat ware vryheid en lewensverruiming nie meer moontlik is nie. Die aanpaksels van die rasionalisme op die Westerse beskawing veroorsaak dat die ware bevryding wat die Christelike lewensvisie bied, nie meer ontvang word nie. Die rede oorheers en geloof word ondermyn. Die Afrika-lewensvisie is nie soos die Westerse beskouing onderworpe aan die sekularisering en rasionalisme nie - die vryheid van geloof speel volgens hom 'n veel groter rol. Daarom is Van der Walt van oortuiging dat die vryheid van geloof en dus die oopheid vir die Christelike Reformatoriese lewensvisie in Afrika groter is ten opsigte van die geloof as ten opsigte van die rasionalistiese Westerse denke.

\section{Enkele probleme in die Westerse denke kan uitgewys word:}

- Oorspanning van die vryheidsideaal en daarmee saam die besondere beklemtoning van individualiteit.

- Oorspanning van die wetenskapsideaal soos wat dit juis neerslag vind in die Westerse denke en die gepaardgaande en gevolglike sekularisme.

Van der Walt toon ook aan dat daar in die Afrika-beskouing duidelike probleme bestaan:

- Inperking van individualiteit en oorspanning van kommunaliteit.

- Oorspanning van die geesteswêreld. 


\section{Reaksie op The Liberating Message}

Om die probleem te hanteer benader Van der Walt dit vanuit die Afrikakonteks. Daarvoor kry hy lof en kritiek. Van Wyk (1995:274) skryf: "Daar is weining ander (teologiese) filosowe aan my bekend wat meer erns maak met 'n Christelike filosofie in Afrika-konteks as Van der Walt". Voorts het hy waardering vir die Skriftuurlike en Skrifmatige benadering wat die skrywer openbaar en hy bevestig dat 'n nuwe tendens al meer in die Christelike filosofie na vore tree, naamlik om die koninkryk van God as sentrale tema te ontwikkel. Hy gaan voort: "Dit val op dat die skrywer telkens uiterstes probeer vermy en op soek gaan na 'n derde weg." Op grond van 'n vroeëre werk, maar ten opsigte van sake wat weer in The Liberating Message voorkom, maak J.H. Smit (1992:385) dié opmerking:

Een van die sinvolste afdelings in die boek [Vensters op die werklikheid - PV] is die vergelyking van die tradisionele Afrikakultuur en die moderne Westerse kultuur. Hier is dit veral die ontleding van die holistiese religieuse oriëntasie van die tradisionele Afrikakultuur en die dualistiese religieuse belewing van die Westerling wat tot nadenke stem. Ook die karakterisering van die kommunalistiese en indiwidualistiese lewenstyle is briljant. Dit is hierdie stof wat oortuigend bevestig dat die skrywer van Afrika is, krities-solidêr: vir die uitbouing van gemeenskaplike waardes en 'n Suid-Afrikaanse nasieskap is dit essensiëel.

Ook Kritzinger (1995:423) beklemtoon die volledigheid van die benadering. Bartholomew (1994:41) skryf: "Bennie is unashamedly reformational in his worldview and philosophy. This is the great strength of his book; one gets a rich insight into a unified Christian worldview steadily working its way through all of life and leavening the whole loaf". Schrotenboer (1994:621) noem enkele hoofgedagtes, waaronder die volgende van belang is: "The Christian worldview, supported by a Christian philosophy, can provide the antidote against the secular, pluralist thinking of the West and dualist Christian thought". Nie alleen die Westerse denke nie, maar ook die Afrika-denke word egter vernuwe.

Coheen (1995:31) kritiseer egter die wyse waarop die Afrikanisering voltrek word en vra of Van der Walt genoegsaam rekening hou met Afrika se eie hantering van wêreldbeskouing. Kontekstualisering is geen oppervlakkige onderneming nie en die vraag is of Van der Walt genoegsaam kennis neem van die bestaan van die eie Afrika-wêreldbeeld, in dié opsig dat die Reformatoriese beskouing in Westerse gewaad nie aangebied kan word as daar nie in ag geneem word dat selfs die beskouing in Afrika radikaal verander nie. Coheen (1995:31) skryf: "If I am reading Van der Walt rightly at this point, I have grave concerns that this study 
will be experienced by Africans as one more imperialistic attempt to impose a Western formulation of the gospel or worldview as normative".

Van der Walt wil die ingewikkelde probleem van die implikasies van die Christelike lewensvisie ondervang deur van 'n openbaringsbegrip gebruik te maak waarin dit duidelik gestel word dat God Hom in die hele skepping openbaar. Van Wyk (1995:275) skryf: "Die skrywer ontwikkel 'n wye openbaringsbegrip (57-80), waarin die Skrifopenbaring wel figureer maar dit nie duidelik word dat hiérdie openbaring 'duideliker' en 'meer volkome' is as die skeppingsopenbaring nie".

Daarmee saam hang Smit (1992:385) se kritisering van Van der Walt se hantering van die wet:

Ek is nie seker of ek die bedoeling goed begryp nie, maar om te beweer dat die wet 'n derde realiteit naas God en skepping verteenwoordig, oortuig my nie. Daar word gesë: 'Die wet is naas God en die kosmos 'n aparte realiteit' en 'n paar reëls verder: 'Dit is belangrik om daarop te let dat God sy wil vir die dinge en in die dinge openbaar' (p. 130). Dis geen probleem om te aanvaar dat die wette God se gekonkretiseerde skeppingswil is nie, maar word die wette dan 'n aparte realiteit?

Bartholomew (1994:42) stel die standpunt dat Van der Walt se beskouing oor openbaring teenkanting uitgelok het en nie duidelik genoeg is nie.

Wat dus duidelik is, is dat Van der Walt 'n totaalvisie op die werklikheid wil stel wat volledig Christelik is en wat die totale lewe insluit, maar wat ook vir die unieke probleme van Afrika relevant is. Hierdie totaalvisie word gerugsteun deur 'n omvattende openbaringsbegrip.

\section{4. 'n Christelike lewensvisie vir Afrika soos aangebied in The Liberating Message}

Coheen (1995:31) se voorafgaande stelling is na my mening relevant. B.J. van der Walt stel nie 'n eie Christelike lewensvisie vir Afrika daar nie, maar gee besonder duidelike riglyne vir 'n algemeen-geldende lewensvisie wat, volgens hom, ook relevant is vir Afrika, maar vanuit die Reformatoriese beskouing - 'n beskouing wat na my mening nog ingebed is in die Westerse lewensvisie. Of die derde weg wat hy wil opgaan, naamlik om 'n nuwe visie naas die Westerse en Afrika-visie te open wat dan wel vir Afrika relevant is, geslaagd is, moet gedebatteer word. Die vraag wat aan die orde is, is of daar wel 'n eie Afrika-interpretasie van die Reformatoriese lewensvisie is wat volkome reg laat geskied aan sowel die Afrika- as die Reformatoriese lewensvisie. 
In hoofstuk 5 word die sentrale temas goed belig. Hier gaan dit om die verskil tussen 'n radikaal Christelike lewensvisie en 'n dualistiese Christelike lewensvisie. In die dualistiese Christelike lewensvisie word die Bybelse perspektief volgens Van der Walt (1994:110) verduister weens die feit dat God se heerskappy oor elke duimbreedte van ons bestaan nie erken word nie. Daar word 'n skeiding aangebring tussen sekulêr en godsdienstig, tussen die God van die filosowe en die God van die Bybel, aarde en hemel, vlees en gees, politikus en priester (of geestelike), ensovoorts. Die Griekse skeiding tussen profaan of sekulêr en heilig of geestelik word in die Christelike lewensbeskouing ingedra (Van der Walt, 1994:111). Volgens Van der Walt (1994:111) was dit veral Thomas Aquinas wat die mens se geloof en godsdiens van die res van sy lewe geskei het. Die Bybel en alles wat met die mens se verhouding met God te doen het, word bonatuurlik. Natuur en genade word dan geskei, laasgenoemde word hoër en eersgenoemde laer aangeslaan. Die kerk verkry dan wel in dié tyd nog beheer oor die natuur, soos byvoorbeeld blyk uit 'n kerklike universiteit in plaas van 'n Christelike universiteit (Van der Walt, 1994:111). Van der Walt oordeel juis anders.

Van der Walt (1994:114) maak sy posisie baie duidelik:

The division of creation into profane (secular) and sacred (holy) spheres originated (as indicated above) in pagan thought. It is not a Biblical idea at all. The Bible clearly teaches that everything which God created was good. Certain parts or sections of creation (the socalled lower ones) are not by nature bad or unimportant. And when Adam fell into sin, the whole of man and the entire creation were affected.

Van der Walt (1994:114) gaan voort om aan te dui dat daar sedert die sondeval twee duidelik onderskeibare denkrigtings ten opsigte van die skepping is, naamlik gehoorsaamheid en diens aan God en ongehoorsaamheid of afval van God, en dit het betrekking op die "geestelike" en "natuurlike" bestaan.

Wanneer Van der Walt (1994:127) nou die Christelik-filosofiese uitgangspunte stel, maak hy dit duidelik dat ses onderskeidinge van belang is:

- Die onderskeiding tussen God en sy skepping.

- Die onderskeiding tussen hemel en aarde.

- Die onderskeiding tussen God se skeppingsordinansies en dit wat daaraan onderworpe is.

- Die onderskeiding tussen die verskillende onverminderbare fasettte of wyses van bestaan in die aardse werklikheid. 
- Die onderskeiding tussen verskillende fases van die ontwikkeling van die aardse skepping.

- Die onderskeiding tussen struktuur en rigting.

Die mensbeskouing wat hierop volg, is van deurslaggewende belang. Van der Walt (1994:157) beskryf die mens vanuit die volgende belangrike perspektief:

We could say (and this is a well-known Biblical concept): man is at once a gift (the crown of creation) and a duty (his task being to be a steward of God's creation). Man is the only creature of whom this can be said. Matter, plants and animals are also wonderful creatures of God, but they merely are. There is no should added to their existence. It is only to man that God has given the calling to become that which he is. His status and his calling are closely related.

Wanneer Van der Walt (1994:183) die kriteria hierbo genoem op die Afrika-mens toepas, meen hy dat die Afrika-mens voor die uitdaging staan om meer inisiatief aan die dag te lê, meer oop en meer dinamies te wees. Die vraag is inderdaad of die Christelike lewensvisie dié moontlikheid skep binne die Afrika-wêreldvisie of daarbuite.

Van der Walt (1994:199) plaas die Afrika-kultuur en die Westerse kultuur naas mekaar en wys op die uiteenlopende benaderings wat by hulle voorkom. In hierdie verband kan twee aspekte uitgelig word, naamlik die geesteswêreld en kommunalisme. Hy beskryf die Afrikakultuur se houding (Van der Walt, 1994:199) só: "[The] Spiritual world [is] very real and important, because it determines and balances the physical world". Die Westerse patroon word só geformuleer: "[The] Natural-physical world [is] real and important - spiritual world is simply superstition". En oor kommunalisme ("Communalism (NB: not communism or socialism)" sê hy (Van der Walt, 1994:204) die volgende: "First the community, then the individual. (I am because we are. I share in the community, therefore I exist.)", terwyl die Westerse patroon individualisme ("Individualism") veronderstel: "First the individual, then the community or social relationships. (We are, because I am. The community exists, because it is constituted by individuals.)" Die kommunalisme word deur Van der Walt (1994:210) as van die uiterste belang beskou om die Afrika-gees te begryp.

Watter oplosssing bied Van der Walt (1994:251)?

In Scripture both the unique individuality (cf. John 21:20, 21) and the communal quality (cf. 1 Cor. 12:12-27) of the human person are recognised as fully complementary dimensions of human experien- 
ce. There is no tension or conflict between them and neither is given priority over the other.

Starting from the central Biblical message of the Kingship of God, we have to realise that both individualism and communalism involve a fundamental denial of the Gospel.

Die koningsheerskappy van Jesus Christus eis die hele lewe op; nie die gemeenskap en ook nie die individu kan daarop aanspraak maak nie.

Hiermee het Van der Walt by die sentrale tema van sy beskouing gekom, naamlik die koningskap van God en die heerskappy van God in sy koninkryk (1994:308):

In response to the dualistic way of thinking, we advocate the holistic Biblical perspective of the kingdom of God. The kingdom of God (as already indicated in previous chapters) is the central concept in Scripture. In contrast to the views of traditional Christianity, church structures are not all that important according to the Word of God. The kingdom of God is also all-encompassing, it includes the whole of creation.

Volgens Van der Walt moet sowel die Afrika-kultuur as -wêreldbeskouing, asook die Westerse wêreldvisie aanpas by die koninkryk van God. Dit lei uiteindelik tot die verchristeliking van hoër onderwys, politiek, wetenskap en ook besigheid.

Dit kan nie beweer word dat Van der Walt meen dat hy met The Liberating Message self die Afrikanisering van die Reformatoriese beskouing voltrek het nie. Hy wil egter tog aantoon dat die Reformatoriese beskouing in Afrika kan tuiskom.

\section{Gespreksvrae}

In die debat is die vraag wat hier gestel word die volgende: slaag Van der Walt daarin om die bevrydende woord vir Afrika vanuit die Reformatoriese lewensvisie te spreek, of is daar nog 'n beslissende verskil wat oorbrug moet word tussen die Reformatoriese lewensvisie en die Afrikalewensvisie? Wat nou indringend bespreek moet word, is of The Liberating Message wel 'n Reformatoriese lewensvisie vir Afrika daarstel. Enkele vrae is van belang.

\subsection{Vra die koninkrykskonsep 'n aanpassing binne die Afrika- beskouing?}

'n Moontlike gespreksvraag is die volgende: is dit moontlik om met die konsep van die koninkryk van God, soos deur Van der Walt (vgl. ook 
1999b:17) en ook andere, byvoorbeeld J.A. Heyns (1982:29, 1986:3862, 1988:339) en D.F.M. Strauss (1978:246 e.v.) uitgewerk is, die Afrikalewens- en wêreldbeskouing te betree sonder om inmiddels te moet erken dat groot aanpassing nodig is?

Afrika se wêreldvisie word bepaal deur die geesteswêreld waarin individualiteit en verantwoordelikheid 'n mindere rol speel. Die konsep van die koninkryk van God herstel menslike verantwoordelikheid. Hierdie menslike verantwoordelikheid roep die mens op tot nuwe lewe voor God op alle lewensterreine.

\section{J.A. Heyns (1982:195) skryf oor die mens as persoonlike wese:}

Die persoon van die mens, as aanduiding van sy ekheid, is die ruimte waarbinne hy as mens bestaan en die oorsprong van waaruit hy ' $n$ verskeidenheid van funksies of take verrig en hy as 'n lewende, denkende, willende, spelende, etende, pratende, arbeidende, wetenskap- en kunsvormende, selfverwerklikende, doelnastrewende, etiese en godsdienstige wese bekend word.

Hierdie aspek van die mens se bestaan word duideliker uitgebeeld in die Westerse bestaan.

Hierdie siening verskil radikaal van die simbiose met die geestesmagte waarin die Afrika-mens lewe. Die helder denke wat ingesluit word in menslike verantwoordelikheid wat kenmerkend is van Westerse denke bring radikale verandering teweeg wanneer dit met die Afrika-denke in verband gebring word.

Daar is plek vir die Afrika-beskouing oor die waarde van die mens en die waarde van die lewe binne 'n omvattende beskouing oor die koninkryk van God, maar daar moet erken word dat, ook binne die raamwerk van die koninkryk van God, dit nog groot verruiming moet ondergaan. Daarmee word aangesluit by Berkhof (1973:531) se gedagte dat erken moet word dat die Westerse mens wel deur die Christelike beskouing beïnvloed is, alhoewel daarmee beslis nie bedoel word dat die Westerse beskouing die absolute gestalte van die Christelike is nie. Berkhof (1973:531) skryf egter wel:

Zo komen we toch tot de conclusie dat het christelijk ferment een beslissende rol heeft gespeeld in het ontstaan en de ontwikkeling van de regels en doelstellingen van de europees-amerikaanse samenleving. Haar kenmerken van individualisering, humanisering, socialisering, verzakelijking en toekomsgerichtheid moeten primair als doorwerking van het Evangelie worden verstaan. 
Kan die Afrika-beskouing, aan dié ander kant, die magiese geestewêreld en kommunalisme afwys en die Christelike Reformatoriese visie omhels? Dit is 'n vraag wat nog baie aandag moet ontvang. Die vraag word dus gestel of die Afrika-beskouing nie veel groter "verandering" moet ondergaan as wat Van der Walt veronderstel nie.

\subsection{Kan kommunikasie nie ook ruimte skep vir die individu nie?}

Die vraag ontstaan of die Afrika-konsep van kommunalisme hoegenaamd aangepas word om die groter ruimte wat ook in die koninkryk van God vir die individu bestaan te skep?

Individualiteit is nie maar 'n uitruilbare konsep nie. Individualiteit waarborg die menswees van die mens voor God. In sy individualiteit word hy of sy deur God aangespreek, vrygespreek en word hy of sy nuwe mense voor God. Hulle bestaan in die gemeenskap, en hulle bestaan raak die hele gemeenskap, maar Afrika-kommunaliteit veronderstel dat die individualiteit in 'n groot mate opgehef word (Van Rooy, 1997:105).

Die Afrika-konsep van kommunaliteit kan nie maar net aangepas word om nou ook individualiteit in te pas nie. Die mens in Afrika is sy kommunaliteit. Hy word deur dié magte beheer. Wanneer hy dit prysgee, sou hy nie meer inpas in die aanvaarbare gemeenskapsgrense wat juis so vir hom of haar gestel word nie. Die vraag is nou hoeveel van die Afrikakonsep behoue bly as beweer word dat die Christelike evangelie die kommunalisme vernuwe? Van der Walt (1994:251) beweer tereg dat die evangelie nie net individualiteit beklemtoon nie, maar dit word tog op so 'n wyse beklemtoon dat die absolute eis van Afrika-kommunaliteit daarmee afgewys word.

Van Niekerk (1992 en 1996) se insiggewende werke in dié verband dui aan dat daar diepgaande verskille tussen die verstaan van die Westerse en die Afrika-mens bestaan. Van Niekerk skryf (1992:10) onder andere die volgende:

Die wit wêreld het die krag van die swart wêreldbeskouing totaal onderskat. Afrika het alles aanvaar wat die Weste vir hom gegee het en aan hom opgedwing het, en dit probeer inpas in die groter geheel van sy eie wêreldbeskouing. Daardie basiese geheelbeeld het hy nie prysgegee nie. Tradisionele uitgangspunte, hoewel soms oënskynlik ondergeploeg, is merkwaardig gehandhaaf. Intussen het die Weste ook die Christelike kerk - gemeen dat Afrika se uiterlike aanvaarding van hulle aanbod die teenstellende ou dinge uitsluit.

Oor die lewensbeskouing van die Afrika-mens skryf Van Niekerk (1996:9): 
Die lewe bestaan uit 'n ewewig en opeenvolging van teenstrydige magte - krag en swakheid, siekte en gesondheid, lewe en dood, droogte en reën, honger en versadiging, skaarste en oorvloed.

Geloof in die onverbiddelike sirkelgang van vernietiging en regenerasie het 'n gevaarlike uitloper. Dit laat sien vernietiging as voorvereiste vir herlewing.

Van Niekerk se oplossing is voortgaande kommunikasie. In kommunikasie lê die uitsuiwering van die gedagtes van die Weste en van Afrika. Daarom beskou hy sending en ekumene en dus veral die beklemtoning van die eenheid van die kerk, as 'n moontlike korreksie op postmodernistiese wanpersepsies oor sending (Van Niekerk, 1998:377). Van der Walt se oplossing lê in die volg van 'n derde weg - nie Westerse rasionalisme nie en ook nie Afrika-magie nie, maar die Reformatoriese lewensbeskouing waarin die hele lewe totaal onder gesag van God se heerskappy gestel word. Van der Walt se oplossing is beslis meer volledig, maar ook meer idealisties en hou nie genoeg rekening met die gevalle werklikheid nie.

\subsection{Hoe kan die Afrikanisering van die evangelie voltrek word?}

In hierdie opsig moet die vraagstellng eintlik verder uitgebrei word tot die volgende: sal die Afrikanisering van die evangelie en die begrip "koninkryk van God" eers voltrek word as Afrika-teoloë self vanuit die evangelie tot nuwe denke kom, en is die voorlopige pogings tot die proses dus reeds in beginsel onvoldoende?

Daar bestaan geen twyfel nie dat daar ook regstelling in die Westerse beskawing geëis word. Is die regstelling wat geëis word egter op dieselfde vlak as die regstelling wat van die Afrika-beskouing geëis word? Die Westerse beskawing het beïnvloeding vanuit verskeie oorde ondergaan, byvoorbeeld vanuit die Hellenistiese en Romeinse beskouing, maar ook vanuit die Christelike beskouing. Dat daar wel 'n neerslag van die Christelike beskouing plaasgevind het, kan nie ontken word nie.

Die Afrika-beskouing, aan die ander kant, inhibeer die vryheidsideaal van individualiteit en die wetenskapsideaal waar dié vryheidsideaal gestalte kry. Hierdie ideale kan Christelik bepaal word, maar kan die afwesigheid daarvan wel Christelik ingevul en so opnuut bepaal word? Na my mening is Van der Walt van mening dat dit wel moontlik is. Ek is van mening dat dit 'n groot verskuiwing in Afrika se denke, wat diepgaande besinning van Afrika se eie denkers sou vereis, sou behels.

Hierin lê na my mening die groot uitdaging. Ten spyte van die besonder volledige poging bly Van der Walt se aanbieding Westers. Afrikanisering 
sal dus slegs kan slaag as die gestelde probleem ernstig deur Afrikafilosowe en -teoloë onder oë geneem word en dan ook vanuit daardie perspektiewe bespreek word. Dit beteken dat vanuit die Afrikaperspektief besonder eerlik na die probleem gekyk en na die oplossing gestreef moet word. Daar sal inderdaad na die positiewe van die Westerse denke gekyk moet word, erkenning daaraan gegee moet word en dan deurgestoot moet word tot vernuwende Afrika-denke. Turaki (1999:319-320) wend reeds 'n poging aan om 'n eie Afrika-perspektief te gee. Hy is van mening dat 'n relevante en Bybelse teologie nodig is waarin die verhouding van die Bybel tot die Afrika-lewensvisie duidelik na vore kom. Turaki (1999:320) sê onder andere:

It is not a search for continuity or discontinuity between Christianity and the African pre-christian religious heritage, but it is identifying (1) areas of human and religious communality and points of contact as bridges to effective Gospel communication and Christian witness and evangelism; (2) it is ascertaining truth and error in the African pre-Christian religious heritage from Biblical perpective and (3) it is developing a theological method of approaching the traditional religions and cultures in Africa.

Westerse kritiek word dikwels nog eenkant toe geskuif as paternalisme. Uit Afrika moet egter kritiese stemme gehoor word teenoor Afrika self en daar moet gehoor gegee word aan die stemme. Die uitgangspunt om self krities vanuit die evangelie die stem van die evangelie vir Afrika te laat hoor, soos Van der Walt self voorstel, is egter uiters sinvol.

Ten opsigte van 'n Christelike Afrika-filosofie skryf Van der Walt (1998: 387):

Ek sien ' $n$ eventuele Christelike Afrikafilosofie as 'n filosofie wat by uitstek bevrydend is. Aan die een kant glo ek dat 'n Christelike filosofie vanuit Afrikabodem 'n belangrike bydrae kan lewer om ons kontinent van eksterne Westerse oorheersing (kyk hierbo) te bevry. Aan die ander kant kan so 'n Christelike Afrikafilosofie 'n onskatbare bydrae lewer om oor die talle unieke interne vraagstukke van Afrika te besin en bevrydende perspektiewe as moontlike oplossings aan te bied.

Die bydrae van Van der Walt om die Afrika-mens op te roep om self betrokke te raak en om kennis te neem van die Reformatoriese beskouing verdien die aandag wat dit reeds in Afrika geniet - die kritiese vrae ten spyt. 


\section{Slot}

Die geweldige uitdaging is met groot moed en oortuiging deur Van der Walt aangepak, maar ek is van mening dat die Afrika-gees nog te ontwykend is om binne die gestelde konsepte vasgevat te word. Soos daar ook in die vroeg-Europese wêreld groot aanpassing nodig was met die voltrekking van die verchristeliking van die samelewing, so sal dit in Afrika ook groot verskuiwings veronderstel, wat nou maar eers 'n aanvang geneem het. Daar kan nie beweer word dat die proses in die Westerse wêreld voltrek is nie - soms is dit trurat (die sekulariseringsproses) - maar Afrika sal self nog grondig in denke moet verander. Van der Walt se derde weg open die moontlikheid van nuwe denke - die optimisme moet egter getemper word met groter realisme.

\section{Bibliografie}

BARTHOLOMEW, G. 1994. Review: The Liberating Message. Many to Many, (7):4142, Febr/March.

BERKHOF, H. 1973. Christelijk geloof. Nijkerk : Callenbach.

COHEEN, M. 1995. Review: The Liberating Message. Pro Rege, 23(3):30-31, March.

HEYNS, J.A. 1982. Teologiese etiek. Deel 1. Pretoria : N.G. Kerkboekhandel.

HEYNS, J.A. 1986. Teologiese etiek. Deel 2/1. Pretoria : NG Kerkboekhandel.

HEYNS, J.A. 1988. Teologiese etiek. Deel 2/2. Pretoria : N.G. Kerkboekhandel.

KRITZINGER, J.J. 1995. Resensie: The Liberating Message. Skrif en Kerk, 16(2): 422-424.

SCHROTENBOER, P.C. 1994. Review: The Liberating Message. Calvin Theological Journal: $620-621$, Nov.

SMIT, Kobus. 1992. Resensie: Vensters op die werklikheid. Koers, 57(3):383-386.

STRAUSS, D.F.M. 1978. Inleiding tot die Kosmologie. Bloemfontein : SACUM.

TURAKI, Y. 1999. Christianity and African Gods. A method in theology. Potchefstroom : PU for CHE. (IRS Series F.2 no. 75.)

VAN DER WALT, B.J. 1994. The Liberating Message. A Christian Worldview for Africa. Potchefstroom : PU for CHE. (The Institute for Reformational Studies. F.3 no. 44.)

VAN DER WALT, B.J. 1998. 'n Christelike Afrikafilosofie - 'n drievoudige uitdaging. In die Skriflig, 32(3):381-388.

VAN DER WALT, B.J. 1999a. Visie op die werklikheid. Die bevrydende krag van 'n Christelike lewensbeskouing en filosofie. Potchefstroom : PU vir $\mathrm{CHO}$. (Wetenskaplike Bydraes van die PU vir CHO. Reeks F3. No. 48.)

VAN DER WALT, B.J. 1999b. Godsdiens en samelewing. Christelike betrokkenheid op die markplein. Potchefstroom : PU vir $\mathrm{CHO}$. (Wetenskaplike bydraes van die PU vir CHO. Reeks F3 no. 51.)

VAN NIEKERK, A. 1992. Saam in Afrika. Kaapstad : Tafelberg.

VAN NIEKERK, A. 1996. Anderkant die reënboog. Kaapstad : Tafelberg.

VAN NIEKERK, A. 1998. Postmodernisme en NG Sending in die Nuwe Suid-Afrika. Ned. Geref. Teologiese Tydskrif, 39(4):367-378.

VAN ROOY, J.A. 1997. Scriptural ethical principles and traditional African ethics. In die Skriflig, 31(1 \& 2):93-106.

VAN WYK, J.H. 1995. Resensie: The Liberating Message. In die Skriflig, 29(1 \& 2): 273-276. 


\section{Kernbegrippe:}

Afrika-lewensvisie

bevrydende woord

Christelike boodskap vir Afrika

individualiteit

kommunalisme

Reformatoriese lewensvisie

\section{Key concepts:}

a liberating word

Africa worldview

Christian message for Africa

communality

individuality

Reformational worldview 